\title{
В.А. Шнирельман
}

\section{АРХЕОЛОГИЯ, КУЛЬТУРНОЕ НАСЛЕДИЕ, ВАНДАЛИЗМ И ВООРУЖЕННЫЕ КОНФЛИКТЫ}

\author{
Статья публикуется в соответствии с планом научно-исследовательских работ Института этнологии и антропологии РАН. \\ Статья представляет расширенный вариант доклада, прочитанного на юбилейной ХVIII Международной Западносибирской \\ археолого-этнографической конференции «Западная Сибирь в транскультурном пространстве Северной Евразии: итоги \\ и перспективы 50 лет исследований ЗСАЭК», состоявщейся 16-18 декабря 2020 г. на базе Томского государственного \\ университета.
}

\begin{abstract}
Рассматривается актуальная проблема социальной роли археологии в условиях современности, когда неожиданно для себя археология оказывается в центре этнополитических или этноконфессиональных конфликтов. На материале мирового археологического наследия автор анализирует причины намеренного уничтожения памятников в ходе войн, варварских действий политических радикалов, религиозных конфликтов, манипуляций с образом прошлого. Сделан вывод, что археолог не может оставаться вне политики, при этом он должен противостоять шовинизму и расизму.

Ключевые слова: археология; культурное наследие; конфликты; войны; вандализм; этика.
\end{abstract}

Проблема исторического наследия - это дитя XIX в. с его жадным интересом к национальной истории. Историческое наследие долго воспринимали как нечто хорошо оформленное и ценное, с железной последовательностью передававшееся от предков к потомкам. Но в 1970-1980-х гг. стало приходить понимание того, что как историческое наследие, так и археологические факты являются конструктами, которые по-разному и в разные периоды выстраиваются как обществом в целом, так и его отдельными группами и тесно связаны с идентичностью и социальной практикой [1-6; 7. C. $107 ; 8$. C. $23 ; 9-10]$.

Курс на приверженность «традиционным ценностям», выступающий интегральной частью государственной консервативной повестки дня, требует однозначного определения того, что именно понимается под историческим наследием, как, кем и для каких целей из безграничного наследия прошлого отбираются материалы, предъявляемые обществу в качестве «исторического наследия», и как именно они интерпретируются. В поликультурном и полиэтничном государстве это грозит недопониманием и конфликтами, так как региональные, конфессиональные и этнические группы нередко имеют собственный взгляд на прошлое, расходящийся с тем, которого придерживаются в федеральном центре. Причем речь идет не только о прошлом, ведь образ прошлого сплошь и рядом используется для легитимации современных политических прав или требований. Вот почему идеология этнополитических конфликтов, как правило, всемерно эксплуатирует образы прошлого и апеллирует к историческому наследию, - все это снабжает конфликт символическим языком.

Противоборствующие стороны это хорошо понимают и всеми силами стремятся развенчать представления друг друга о прошлом, что и ведет к «войнам памяти» и бесконечным обвинениям противника в «фальсификациях» и «манипуляциях» (см., напр.: [1112]). Такая обстановка иной раз создает смертельную опасность для культурного наследия, и ему грозит полное уничтожение. В случае военных столкновений ведется борьба с чужим историческим наследием с целью стереть с лица земли любые напоминания о враге. В контексте тяжелого конфликта переосмысление прошлого ведет к уничтожению древних памятников или археологических материалов, связанных с неприемлемым образом предков или, что чаще, с чужими предками. Фактически уничтожение исторического наследия как способ дегуманизации противника сопутствует этническим чисткам и геноциду [13-14].

Bce это показали недавние войны на Балканах, в Абхазии, армяно-азербайджанская конфронтация, гибель памятников в Чечне, массовое разрушение археологических древностей во время недавних войн в Ираке, Сирии и в других регионах мира (см., напр.: [11; 12; 14; 15; 16. Р. 116-117; 17. Р. 59; 18-25]).

До сих пор специалисты уделяли мало внимания тому, что означают выводы и заключения археологов в обстановке острого этнического конфликта. Сознавая опасность таких споров и конфликтов, некоторые авторы ставят вопрос об инструментализации археологии, что рождает проблему моральной ответственности археологов, подтверждающих своими исследованиями ту или иную точку зрения и, тем самым, неумышленно раздувающих межгрупповые распри или сепаратизм. В такой ситуации стремление археологов поддержать одну из сторон ведет к идеологической борьбе между самими археологами, выступающими по разные сторон баррикад.

Все это требует от археологов тонкого понимания того, в какой мере и каким образом добываемое ими знание служит политике, лежащей далеко за рамками археоло- 
гии, а также кто именно является субъектом, а кто жертвой этой политики и во имя чего она проводится.

Во время войн и мятежей культурные ценности страдают и от банального мародерства. Так, в ходе американской войны в Ираке в апреле 2003 г. был разграблен Национальный музей в Багдаде [26]. А в янваpe 2011 г. во время беспорядков в Египте мародеры расхищали сокровища местных памятников и музеев, включая знаменитый Египетский музей в Каире [2729]. Иной раз и местное население занимается нелегальной торговлей древностями, чтобы свести концы с концами, и именно обнищание стало главной причиной того, что после 2003 г. поиск и продажа древностей превратились в Ираке в «национальный промысел». Причем в ряде случаев люди верят в то, что предки это одобряют, спасая их от нищеты [30. Р. 58; 31. Р. 74-79, 88-89; 32. Р. 187; 33].

Например, сицилийцы грабят могилы своих предков, считая, что оставленные там ценности принадлежат им по праву наследия. А вот индейцы-майя свободно грабят древние гробницы, считая их «чужими», тогда как свое наследие они склонны сохранять [4. Р. 22]. Мало того, с точки зрения американских индейцев, именно антропологи и археологи занимаются расхищением их культурного наследия [34. Р. 99].

Памятники прошлого уничтожаются и по религиозным причинам. В Мексике и Перу еще в XVIXVII вв. миссионеры сознательно разрушали археологические памятники, чтобы коренные жители забыли свое дохристианское прошлое. В Саудовской Аравии в 1930-х гг. разрушали христианские и иудейские памятники. В Египте при президенте Насере наблюдался упадок интереса к доисламскому прошлому [35], а в школах Иордании история доисламского периода и ныне не преподается [36]. В Иране после исламской революции археология как «служанка деспотии» утратила свой былой престиж, и одно время там уничтожались памятники домусульманского периода, а археологи подвергались гонениям [37; 38. Р. 57, 59-62].

В марте 2001 г. по воле властей Талибана в Афганистане были разрушены многие статуи домусульманского времени, включая уникальные гигантские статуи Будды в Бамьяне [14. Р. 122-126; 39-40; 41. Р. 161162]. Тогда же уничтожили все изображения Будды в Национальном музее в Кабуле. Осенью 1999 г. по инициативе мусульманского духовенства были проведены ремонтные работы под мечетью аль-Акса на Храмовой горе в Иерусалиме, в результате чего уничтожен важнейший археологический слой домусульманской эпохи [14. Р. 111; 42. Р. 501] $]^{1}$.

В начале февраля 2012 г. на Мальдивах после государственного переворота исламисты уничтожили статуи Будды в Национальном музее [43]. Во второй половине того же года боевики-исламисты разрушили суфийские мавзолеи в Тимбукту на севере Мали, сочтя их языческими [44-45; 46. Р. 117]. В марте 2012 г. великий муфтий Саудовской Аравии призвал к разрушению христианских церквей [47], но, к счастью, этого не произошло.

Колоссальные потери историческое наследие понесло в результате варварской деятельности ИГИЛ (террористическая организация, запрещена в РФ) в Ираке и Сирии в 2015-2017 гг., когда исламские боевики сравняли с землей руины древнеассирийского Нимруда [48], разрушили остатки древнего города Хатры [49], уничтожили ряд уникальных памятников Пальмиры и разграбили 12 музеев, включая музей в Мосуле. Разрушению и осквернению подверглись также христианские, шиитские, суфийские и йезидские часовни и гробницы [50-54]. В ООН и ЮНЕСКО все это определили как военные преступления. Иногда такое целенаправленное уничтожение культурного наследия называют «культурным геноцидом» [55].

Некоторые эксперты объясняли варварские действия исламских радикалов не только покушением на коллективную память местного населения, но и сознательным вызовом мировому общественному мнению и современным ценностям, для чего боевики активно использовали электронные медиаканалы [40. Р. 93-94; 55. Р. 2; 56. Р. 101-102]. Причем иной раз речь шла о постановочных сценах, призванных воспроизвести борьбу средневековых мусульман с идолами для того, чтобы шокировать западных зрителей. С такой точки зрения следовало бы говорить не об архаическом религиозном «иконоборчестве», а о «символическом насилии» путем борьбы за образы и воображение во имя восстановления справедливости и защиты общества от «гегемонизма» так называемых «крестоносцев» [57-58] (ср.: [39. Р. 651-655; 59. Р. 224]. В то же время некоторые авторы видят в этих разрушительных действиях особые ритуалы инициации, направленные на сплочение сторонников радикального ислама («общество джихада»), тем самым демонстрирующих готовность к любому насильственному поведению под властью авторитарного лидера [60].

В намеренном разрушении древностей обнаруживался и символический протест против археологии, в которой мусульманские радикалы видят верное орудие колониализма и неоколониализма $[61]^{2}$. Например, у палестинцев это принимает форму сопротивления претензиям израильтян на их земли [64; 65. Р. 91-94]. В ряде случаев местное население выражает этим свой гнев в отношении деспотических режимов, легитимирующих себя апелляцией к местным древностям [66. P. 223-224].

В любом случае речь идет о символической форме борьбы за политические права или политическую гегемонию, которая ведется путем устрашения противника. И хотя, анализируя эту коллизию, Р. Бивэн сконцентрировал свое внимание на наиболее значимых архитектурных сооружениях [14. Р. 62-65], это в равной мере касается и археологических памятников. Правда, в ряде других случаев, например в Южном Ираке и Палестине, где сохраняются архаические представления, местные крестьяне борются с археологическими памятниками по другой причине, ибо верят в их связь со злыми духами [59. Р. 223].

К сожалению, призывы ЮНЕСКО мобилизовать мировую общественность на защиту культурного наследия Ирака и Сирии имели весьма слабый эффект [67-68]. Против войны, грозящей уничтожением уникального культурно-исторического наследия, выска- 
зался и 6-й Всемирный археологический конгресс, состоявшийся в Дублине в июне-июле 2008 г. [69] Но археологов никто не слушал. Не помогла и Гаагская конвенция 1954 г. по защите культурных ценностей в случае военных конфликтов. А известное выступление оркестра Мариинского театра в Пальмире только спровоцировало новые разрушения, осуществленные боевиками ИГИЛ [70-71].

Уничтожением «чужого наследия» занимаются не только мусульманские фундаменталисты и радикалы. После 1974 г. в северной (турецкой) части Кипра происходила чистка греческих древностей вплоть до расхищения археологических материалов, уничтожения средневековых церквей и запрещения археологических работ [72. Р. 16]. В 1992 г. в Индии индуистские радикалы сравняли с землей средневековую мечеть Бабри Маджид в Айодхье [73]. Во время войны в 1992-1996 гг. в Боснии и Герцеговине хорваты и боснийские сербы целенаправленно разрушали мусульманские, причем сербы - также и католические, святыни и религиозные учреждения [74-76]. В 19982005 гг. в Косово было разрушено 150 православных храмов и более 207 мечетей [20. Р. 262-263].

Война в Ираке в 2003 г. и последующая гибель исторических ценностей мирового значения заставила поставить вопрос об «этическом кризисе в археологии». Ведь за редким исключением археологи ограничились защитой исторических ценностей и хранили молчание по поводу легитимности вторжения американцев в Ирак и гибели массы иракцев. Известный археолог Я. Хамилакис определил это как «безответственность», выражающуюся в заботе о древностях в ущерб заботе о людях [7. Р. 107; 77]. Мало того, он отмечал сконструированный характер этих «древностей», ведь речь шла о смысловом значении археологических находок, но этот смысл придается им самими археологами на основе своих собственных представлений и принятых в науке методик, причем не последнюю роль играет и идентичность этих археологов.

Некоторые археологи поддержали американское вторжение в Ирак, ограничившись ролью профессиональных экспертов, и это вызвало широкую дискуссию о допустимости участия археологов в войне, в частности об их сотрудничестве с военными [69; 78. Р. 205-206]. Ведь немало археологов согласилось на ту или иную форму такого сотрудничества, полагая, что тем самым они смогут уберечь памятники истории от разрушения и восстановить мир [79, 80]. Примечательно, что 6-й Всемирный археологический конгресс не осудил археологов, сотрудничавших с американской армией.

Изучение археологами останков жертв недавних войн и кровавых конфликтов иной раз грешит искажениями истины в пользу победителей [81]. Кроме того, по словам Хамилакиса, те, кто в этих условиях отказались выступать «критическими мыслителями», попали в ловушку, обнаружив живучесть «колониального мышления». Поэтому вставал вопрос о том, перед кем именно археологи должны нести ответственность. Ведь, как резонно отметил Хамилакис, если археологи держатся идеи консервации, то некоторые местные группы предпочитают перестройки и даже разрушение того, в чем археологи видят «историческое наследие». Поэтому, по его мнению, археологам следует откликаться на реальные нужды местного населения и учитывать широкий политический контекст своих исследований, включая национализм, неоколониализм и империализм [7. Р. 107-108].

Недавняя деятельность ИГИЛ в Сирии и Ираке показала справедливость этих рассуждений. К сожалению, несмотря на всю свою своевременность, сплоченные выступления американских археологов и Всемирного археологического конгресса в 2003 и в 2008 гг. против войны, гибели местного гражданского населения и уничтожения исторического наследия не смогли предотвратить дальнейшего обострения ситуации на Ближнем Востоке. Зато тесная связь археологических исследований и исторического наследия с политикой, о чем я когда-то писал [12. С. 546-553; 82; 83] (также см.: [84]), находит все больше подтверждений в окружающей действительности, и это имеет прямое отношение к теме этики в археологии [78, 85].

Огромную угрозу для исторического наследия также представляют «черные копатели» [86]. Так, весной 2012 г. в Анапе грабителями был серьезно поврежден раскопанный накануне древнегреческий храм [87, 88]. Проблема грабительских раскопок является едва ли не эндемичной на Ближнем Востоке [89-90] и в других регионах мира [91-97].

В Англии под посягательством на историческое наследие понимаются: а) нанесение ущерба историческому ландшафту; б) незаконные раскопки и изъятие артефактов из исторического контекста; в) архитектурный грабеж; г) незаконная реконструкция и разрушение исторических зданий [98. Р. 243]. К таким преступлениям одно время относились использование металлодетектора для добычи древностей ${ }^{3}$, кража изделий из драгоценных металлов, кража архитектурных деталей, а также антиобщественное поведение (граффити, мусор и пр.). А кража предметов искусства и незаконная торговля древностями считаются международными преступлениями [98. Р. 244-246].

Таким образом, разрушение исторического наследия преследует следующие цели: грабеж и торговля древностями; лишение противника исторических ресурсов, которые он мог бы использовать для легитимации своих прав; отказ от неприемлемых (языческих) предков; борьба с «неверными» путем уничтожения важных для них религиозных символов; уничтожение символов неоколониализма и деспотии, с которыми иной раз связывается археология; лишение меньшинств исторического наследия во имя единства и консолидации нации. Причем в последние 20-25 лет едва ли не основным фактором уничтожения исторического наследия стали служить религиозные соображения. Главными агентами агрессии в таких случаях являются религиозные общины и движения, а не государства. И если важную роль в этом играет защита идентичности [24. Р. 53], то речь идет о религиозной идентичности, а экономические соображения оказываются второстепенными или вообще не играют никакой роли. Это вовсе не тот этнический национа- 
лизм, о котором еще недавно писали многие авторы [100-101].

В таком контексте возникают важные вопросы: кому именно должны служить археологи - памятникам древности, музеям и музейным ценностям или же живым людям? С чем имеет дело археология - только с древностью или также с современностью? Как использование прошлого в виде товара (коммодификация) соотносится с уничтожением археологических памятников и объектов? [59. Р. 216-217]. Мало того, как показал шведский культурный антрополог К. Холторф, понимание наследия отличается парадоксальностью, и в ряде случаев объект превращается в наследие именно в результате его разрушения [14. Р. 191$192 ; 56]$. Если примерами Холторфу служили разрушенные терактом здания-близнецы в Нью-Йорке и остатки Берлинской стены, то в Москве это можно видеть на примере остатков стены Китай-города или отмеченных памятными знаками мест разрушенных храмов. В память о Великой Отечественной войне в Новороссийске был сохранен металлический остов железнодорожного вагона, а в Волгограде - Дом Павлова. В Хиросиме память об атомном взрыве хранит «Купол Гэмбаку» - каркас разрушенного здания Промышленной палаты. В свою очередь, А. Щенле показал, что древние развалины еще в XVII-XVIII вв. служили предметом почитания и порождали романтические переживания; этим они до сих пор привлекают туристов. Причем если некоторые получают от развалин эстетическое удовольствие, то другие видят в них нечто прямо противоположное [102].

Разумеется, следует всегда помнить, что, хотя археологи имеют дело с остатками умерших культур и цивилизаций, результаты археологических исследований предназначены живым людям, у которых имеются свои особые интересы, заставляющие их по-своему относиться к археологии: высоко ее ценить или, напротив, отвергать; полностью доверять археологическим выводам или принимать лишь то, что служит интересам данного общества или группы, и отвергать то, что идет вразрез с ними. В последние десятилетия западные сторонники постпроцессуальной археологии рассматривают такие коллизии в контексте борьбы за идентичность и склоняются к поддержке коренного населения, для которого легитимация права на историческое наследие звучит справедливым протестом против дискриминации. Поэтому предлагается поддерживать дискриминируемое меньшинство против гегемонии большинства $[8 ; 103 ; 104 ; 105$. Р. 23]. С этим вряд ли можно спорить, но это не снимает все вопросы, и некоторые археологи критикуют такой подход за презентизм и «политизацию» археологии, чреватую серьезными конфликтами [106].

Вместе с тем, заботясь об «идентичности» и понимая ее в примордиалистском духе (или в соответствии c «теорией этноса» в отечественной традиции), архео- логи десятилетиями выстраивали этногенетические схемы, неумышленно обслуживая современную этнонационалистическую политику, апеллирующую к историческому праву. Однако углубление современных представлений об этничности в далекое прошлое не имеет твердых оснований [107-108]. Ведь до европейской колонизации у населения Азии, Африки и Америки не было никаких представлений о «расе» или «этносе», понятия о которых были принесены сюда европейцами. Именно эти привнесенные извне конструкции стали идеологической основой «расовых» и «этнических» конфликтов, что хорошо видно, например, в случае с геноцидом в Руанде.

Следовательно, занимаясь реконструкцией древних процессов, археолог обязан учитывать окружающую политическую обстановку и хорошо понимать, кто и каким образом может использовать плоды его трудов [109]. За последние 30 лет некоторые археологи уже начали осознавать свой сомнительный вклад в создание примордиальных идентичностей $[12,78,104,110-$ 111], и сегодня Холторф предупреждает об опасностях культурализма, делающего упор на неразрывную и непреодолимую связь индивидов с какой-либо конкретной закрытой культурой [112]. По его словам, такой культурализм противопоставляет культурную принадлежность правам человека и приводит не к консолидации поликультурного общества, а к его расколу [Ibid. P. 5-6]. Мало того, сегодня уже очевидно, что такой культурализм не только ограничивает свободу индивида, но и создает почву для современного расизма [113].

Чтобы противостоять этой нездоровой тенденции, нужен такой подход к историко-культурному наследию, который требовал бы как уважения к местному наследию, так и активного участия общественности в его сохранении независимо от того, какой именно группе это наследие принадлежало в прошлом. Причем это не должно препятствовать учету былых процессов гибридизации и креолизации. Следует отчетливо понимать, что культура - это открытая система, что во все эпохи происходили процессы взаимодействия и смешения культур, наследниками чего и являются современные культуры с их гетерогенным историческим багажом [112. Р. 10]. Именно такого подхода всегда придерживались лучшие представители отечественной науки. Однако сложный и неоднозначный современный политический контекст требует от ученого особой чуткости, чтобы искусно лавировать между Сциллой этнонационализма и Харибдой империализма, шовинизма и расизма. Ведь, как с сожалением отмечают некоторые западные ученые, расизм не чужд современной археологии [114].

Следовательно, как показывает современная практика, археолог не может оставаться вне политики. Она непременно затягивает его, начиная от выбора тематики и кончая сделанными им выводами [77. Р. 201].

\section{ПРИМЕЧАНИЯ}

\footnotetext{
${ }^{1}$ В то же время и израильтяне неоднократно разрушали объекты исламского наследия. См.: [14].

${ }^{2}$ Об аналогичном протесте американских индейцев см.: [62. Р. 24; 63. Р. 60].

${ }^{3}$ По новому закону, принятому в 1996 г., использование металлодетектора в Англии и Уэльсе было разрешено. См.: [99. Р. 61].
} 


\section{ЛИТЕРАТУРА}

1. Wright P. On Living in an Old Country. The National Past in Contemporary Britain. London : Verso, 1985. 256 p.

2. Hewison R. The Heritage Industry: Britain in a Climate of Decline. London : Methuen Publishing Ltd., 1987. 160 p.

3. Fowler P. The Past in Contemporary Society: Then, Now. London : Routledge, 1992. 210 p.

4. Lowenthal D. The heritage crusade and the spoils of history. Cambridge : Cambridge University Press, 1998.356 p.

5. Brown M.F. Who owns native culture? Cambridge : Harvard University Press, 2003. 336 p.

6. Smith L. Uses of heritage. London : Routledge, 2006. 368 p.

7. Hamilakis Y. Iraq, stewardship and 'the record': an ethical crisis for archaeology // Public archaeology. 2003. Vol. 3, № 2. P. 104-111.

8. Hamilakis Y. From ethics to politics // Archaeology and Capitalism: From Ethics to Politics. Walnut Creek, CA : Left Coast Press, 2007. P. 15-40.

9. Green L. Archaeologies of Intellectual Heritage? // Ethics and archaeological praxis. New York : Springer, 2015. P. $229-243$.

10. Haber A. Archaeology after archaeology // After Ethics: Ancestral Voices and Post-Disciplinary Worlds in Archaeology. New York : Springer New York, 2015. P. 127-137.

11. Шнирельман В.А. Войны памяти: мифы, идентичность и политика в Закавказье. М. : Академкнига, 2003.245 с.

12. Шнирельман В.А. Быть аланами. Интеллектуалы и политика на Северном Кавказе в ХХ веке. М. : НЛО, 2006.696 с.

13. Gamboni D. The Destruction of Art: Iconoclasm and Vandalism since the French Revolution. London : Reaktion Books, 1997. 416 p.

14. Bevan R. The Destruction of Memory. Architecture at War. London : Reaktion Books, 2006. 240 p.

15. Chapman J. Destruction of a common heritage: the archaeology of war in Croatia, Bosnia and Hercegovina // Antiquity. 1994. Vol. 68, № 258. P. 120-126.

16. Kaiser T. Archaeology and ideology in southeast Europe // Nationalism, politics and the practice of archaeology. Cambridge : Cambridge University Press, 1995. P. 99-119.

17. Silberman N.A. Between past and present. Archaeology, ideology, and nationalism in the modern Middle East. New York : Anchor Books, 1989. 285 p.

18. Garen M. The War within the War // Archaeology. 2004. July / August. P. 28-31.

19. Šulc B. The protection of Croatia's cultural heritage during war 1991-95 // Destruction and conservation of cultural property. London, New York : Routledge, 2005. P. 157-167.

20. Defreese M. Kosovo: Cultural Heritage in Conflict // Journal of conflict archaeology. 2009. Vol. 5, № 1. P. $257-269$.

21. Stone P.G., Farchakh Bajjaly J. Introduction // The Destruction of Cultural Heritage in Iraq. Woodbridge : The Boydell Press, 2008. P. 1-17.

22. Antiquities under Siege. Cultural Heritage Protection after the War in Iraq / L. Rothfield (ed.). Lanham, MD : Altamira Press, 2008.340 p.

23. Cobb E. Cultural Heritage in Conflict: World Heritage Cities of the Middle East : (Masters Thesis). Philadelphia : University of Pennsylvania, 2010.

24. Auwera S. van der. Contemporary Conflict, Nationalism, and the Destruction of Cultural Property during Armed Conflict: a Theoretical Framework // Journal of conflict archaeology. 2012. Vol. 7, № 1. P. 49-65.

25. Фаустова М. Россия поможет восстановить утраченные святыни Косово // Голос России. 2012.16 мapта. URL: http://rus.ruvr.ru/ 2012_03_16/68672459

26. Catastrophe! The Looting and Destruction of Iraq's Past. Oriental Institute Museum Publications / G. Emberling, K. Hanson (eds.). Chicago : The Oriental Institute Museum of the University of Chicago, 2008. 87 p.

27. Журенков К., Епифанова М. Похищение веков // Огонек. 2011. 21 фев., № 7. URL: http://www.kommersant.ru/doc/1580743

28. Египет: мародерство продолжается // Регнум. 2011. 2 марта. URL: http://www.regnum.ru/news/1379839.html

29. Опубликован итоговый список потерь в Каирском музеe // Регнум. 2011. 16 марта. URL: http://www.regnum.ru/news/1384090.html

30. Layton R., Wallace G. Is culture a commodity? // The ethics of archaeology: philosophical perspectives on archaeological practice. Cambridge : Cambridge Univ. Press, 2006. P. 46-68.

31. Hollowell J. Moral arguments on subsistence digging // The ethics of archaeology: philosophical perspectives on archaeological practice. Cambridge : Cambridge University Press, 2006. P. 69-93.

32. Rush L.W. Partnership Versus Guns: Military Advocacy of Peaceful Aproaches for Cultural Property Protection // Ethics and the Archaeology of Violence. New York : Springer, 2015. P. 181-198.

33. Hardy S. Virtues Impracticable and Extremely Difficult: the Human Rights of Subsistence Diggers // Ethics and the Archaeology of Violence. New York : Springer, 2015. P. 229-239.

34. Bendremer J.C., Richman K.A. Human subjects review and archaeology: a view from Indian country // The ethics of archaeology: philosophical perspectives on archaeological practice. Cambridge : Cambridge University Press, 2006. P. 97-114.

35. Hassan F. Memorabilia: archaeological materiality and national identity in Egypt // Archaeology under fire: nationalism, politics and heritage in the Eastern Mediterranean and Middle East. London : Routledge, 1998. P. 200-216.

36. Badran A. The Excluded Past in Jordanian Formal Primary Education: The Introduction of Archaeology // New Perspectives in Global Public Archaeology. New York : Springer Science+Business Media, LLC, 2011. P. 197-215.

37. Abdi K. Nationalism, politics, and development of archaeology in Iran // American journal of archaeology. 2001. Vol. 105, № 1. P. 51-76.

38. Dezhamkhooy M., Yazdi L.P., Garazhian O. All Our Findings Are Under Their Boots! The Monologue of Violence in Iranian Archaeology // Ethics and the Archaeology of Violence. New York : Springer, 2015. P. 51-70.

39. Flood F.B. Between cult and culture: Bamiyan, Islamic iconoclasm, and the museum // The Art Bulletin. 2002. Vol. 84, № 4. P. 641-659.

40. Colwell-Chanthaphonh C. Dismembering / disremembering the Buddhas? Renderings on the Internet during the Afghan purge of the past // Journal of Social Archaeology. 2003. Vol. 3, № 1. P. 75-98.

41. Huyssen A. Present pasts: urban palimpsests and the politics of memory. Stanford : Stanford University Press, 2003. P. 161-162.

42. Silberman N.A. If I forget thee, O Jerusalem: archaeology, religious commemoration and nationalism in a disputed city, 1801-2001 // Nations and Nationalism. 2001. Vol. 7, № 4. P. 487-504.

43. Исламисты на Мальдивах уничтожили в местном музее коллекцию из 30 статуй Будды // newsru. 2012.17 фев. URL: http://www.newsru.com/ religy/17feb2012/maldives.html

44. Исламисты разрушили до основания памятник ЮНЕСКО // РБК. 2012. 30 июня. URL: http://top.rbc.ru/society/30/06/2012/657690.shtml

45. Соловьева H. В Мали исламисты разрушили несколько святынь - захоронений // ИнтерНовости. 2012.23 дек. URL: http://www.internovosti.ru/text/?id=65502

46. Colwell Ch., Joy Ch. Communities and Ethics in the Heritage Debates // Global Heritage: a Reader. John Wiley \& Sons, Inc. Published, 2015. P. 112-130.

47. Фаустова М., Петрова А. Аравийская толерантность // Голос России. 2012. 20 марта. URL: http://rus.ruvr.ru/2012_03_20/68985207

48. Миклашевская А. ИГИЛ сровнял с землей историю Ассирии // Коммерсант-Online. 2015. 6 марта. URL: https://news.mail.ru/ incident/21296437/?frommail=1

49. «Исламское государство» опубликовало видео уничтожения древнего города Хатра // Новая газета. 2015.4 апр.

50. Забродина Е. Кто спасет Пальмиру? // Российская газета. 2015. 21 мая.

51. Рождественская Я. Боевики «Исламского государства» начали разрушать Пальмиру // Коммерсант. 2015.25 июня.

52. Боевики ИГ разбили кувалдами шесть статуй в Пальмире // Лента.ру. 2015. 3 июля. URL: https://news.mail.ru/incident/22547069

53. Филипенок А. Боевики ИГ разрушили часть римского амфитеатра в Пальмире // PБK. 2017.20 янв. URL: http://www.rbc.ru/society/ 20/01/2017/5881ca5e9a79472a1664c588?from=newsfeed 
54. Luke Ch., Meskell L. Archaeology, assistance, and aggression along the Euphrates: reflections from Raqqa // International Journal of Cultural Policy. 2019. 2 April. URL: https://doi.org/10.1080/10286632.2019.1598398

55. Dopelhofer Ch. Will Palmyra rise again? - War Crimes against Cultural Heritage and Post-war reconstruction, 2016. P. 1-12. URL: http://www.ohchr.org/EN/Issues/CulturalRights/Pages/IntentionalDestruction.aspx.

56. Holtorf C. Can less be more? Heritage in the age of terrorism // Public archaeology. 2006. Vol. 5. P. 101-109.

57. Harmansah Ö. ISIS, heritage, and the spectacles of destruction in the global media // Near Eastern Archaeology. 2015. Vol. 78, № 3. P. 170-177.

58. Smith C., Burke H., de Leiuen C., Jackson G. The Islamic State's symbolic war: Da'esh's socially mediated terrorism as a threat to cultural heritage // Journal of Social Archaeology. 2015. Vol. 16, № 2. P. 164-188.

59. Pollock S. Archaeology and contemporary warfare // Annual Review of Anthropology. 2016. Vol. 45. P. $215-231$.

60. Shahab S., Isakhan B. The ritualization of heritage destruction under the Islamic State // Journal of Social Archaeology. 2018. № 2. P. 212-233.

61. De Cesari C. Post-colonial ruins: Archaeologies of political violence and IS // Anthropology Today. 2015. Vol. 31, № 6. P. 22-26.

62. Smith L. Archaeological theory and the politics of culture heritage. New York : Routledge, 2004. 272 p.

63. Nicholas G., Hollowel J. Ethical Challenges to a Postcolonial Archaeology: the Legacy of Scientific Colonialism // Archaeology and Capitalism: From Ethics to Politics. Walnut Creek : Left Coast Press, 2007. P. 59-82.

64. Yahya A. The Archaeological Sites of the West Bank and Gaza. Al Bireh : Abu Ghosh Press, 1998.

65. Kersel M.M. Transcending borders: objects on the move // Archaeologies : Journal of the World Archaeological Congress. 2007. Vol. 3, № 2. P. 91-94.

66. Al-Hamdani A.M. Protecting and recording our archaeological heritage in southern Iraq // Near Eastern Archaeology. 2008. Vol. 71, № 4. P. 223 -224.

67. Lababidi R., Qassar H. Did They Really Forget How to Do It? Iraq, Syria, and the International Response to Protect a Shared Heritage // Journal of Eastern Mediterranean Archaeology \& Heritage Studies. 2016. Vol. 4, № 4. P. 341-362.

68. Leckie L., Cunliffe E., Varoutsikos B. Towards a protection of the Syrian cultural heritage: a summary of the national and international responses. Girona : Heritage for Peace, 2017. Vol. IV. 111 p.

69. Albarella U. Archaeologists in Conflict: Empathizing with Which Victims? // Heritage Management. 2009. Vol. 2, is. 1. P. 105-114.

70. Schoenbaum D. The violins of Palmyra: Soft power projection, then and now // Foreign affairs. 2016. 26 May.

71. Plets G. Violins and trowels for Palmyra: Post-conflict heritage politics // Anthropology Today. 2017. Vol. 33, № 4. P. 18-22.

72. Knap A.B., Antoniadou S. Archaeology, politics and the cultural heritage of Cyprus // Archaeology under fire. London : Routledge, 1998. P. 13-43.

73. Шнирельман В.А. Религия, национализм и межконфессиональный конфликт в Индии // Этничность и религия в современных конфликтах. М. : Наука, 2012. С. 57-109.

74. Tanner M. Croatia: a Nation Forged in War. New Haven : Yale University Press, 1997. P. 285-294.

75. Barakat S., Wilson C., Simcic V.S., Kojakovic M. Challenges and Dilemmas Facing the Reconstruction of War-Damaged Cultural Heritage: the Case Study of Pocitelj, Bosnia-Herzegovina // The Destruction and Conservation of Cultural Property. London : Routledge, 2001. P. $168-181$.

76. Riedlmayer A.J. Destruction of Cultural Heritage in Bosnia-Herzegovina, 1992-1996: a Post-War Survey of Selected Municipalities. Cambridge, MA, 2002. URL: http://hague.bard.edu/reports/BosHeritageReport-AR.pdf

77. Hamilakis Y. The 'war on terror' and the military-archaeology complex: Iraq, ethics, and neocolonialism // Archaeology : Journal of the World Archaeological Congress. 2009. Vol. 5, № 1. P. 39-65.

78. Perring D., van der Linde S. The Politics and Practice of Archaeology in Conflict // Conservation and Management of Archaeological Sites. 2009. Vol. 11, № 3-4. P. 197-213.

79. Stone P. Archaeology and Conflict: An Impossible Relationship? // Conservation and Management of Archaeological Sites. 2009. Vol. 11, № 3-4. P. 315-332.

80. Rush L.W. Partnership Versus Guns: Military Advocacy of Peaceful Aproaches for Cultural Property Protection // Ethics and the Archaeology of Violence. New York : Springer, 2015. P. 181-197.

81. Congram D. Cognitive Dissonance and the Military-Archaeology Complex // Ethics and the Archaeology of Violence. New York : Springer, 2015. P. 198-213.

82. Shnirelman V. Politics of ethnogenesis in the USSR and after // Bulletin of the National Museum of Ethnology. 2005. Vol. 30, № 1. P. 93-119.

83. Шнирельман В.А. Президенты и археология, или что ищут политики в древности // Ab Imperio. 2009. № 1. С. 279-323.

84. Shanks M., Tilley C. Re-constructing archaeology . Cambridge : Cambridge University Press, 1987. 312 p.

85. Archaeology and Capitalism: From Ethics to Politics / Y. Hamilakis, P. Duke (eds.). Walnut Creek, CA : Left Coast Press, 2007. 298 p.

86. Макаров Н.А. Грабительские раскопки как фактор уничтожения археологического наследия России. М. : Ин-т археологии РАН, 2004.43 с.

87. В Анапе вандалы разрушили алтарь древнейшего храма // Kuban.aif.ru. 2012. 9 aпр. URL: http://www.kuban.aif.ru/culture/news/52064

88. Соловьев С. Охотники за черепками. Россия остается Меккой для «черных археологов» // Новые Известия. 2006. 4 авг.

89. Kersel M.M., Luke Ch. Editorial Introduction // Journal of Field Archaeology. 2010. Vol. 35, № 1. P. 99-100.

90. Jacobson D. Vandalism and worse at Herodian sites // Palestine Exploration Quarterly. 2014. Vol. 146, № 3. P. $173-176$.

91. Plundering Africa's Past / P.R. Schmidt, R.J. McIntosh (eds.). Bloomington : Indiana University Press, 1996. 302 p.

92. Renfrew C. Loot, Legitimacy and Ownership: the Ethical Crisis in Archaeology. London : Duckworth, 2000.160 p.

93. Trade in Illicit Antiquities: the Destruction of the World's Archaeological Heritage / N. Brodie, D. Jennifer, C. Renfrew (eds.). Cambridge : McDonald Institute for Archaeological Research, 2001. 172 p.

94. Atwood R. Stealing History: Tomb Raiders, Smugglers, and the Looting of the Ancient World. New York : St. Martin's Press, 2004 . 368 p.

95. Archaeology, Cultural Heritage, and the Antiquities Trade / N. Brodie, M.M. Kersel, Ch. Luke, K. Walkter Tubb (eds.). Gainesville : University Press of Florida, 2006. 364 p.

96. All the King's horses. Essays on the impact of looting and the illicit antiquities trade on our knowledge of the past / P. Lazrus, A. Barker (eds.). Washington : SAA, 2012. 170 p.

97. Folorunso C.A. Research Notes on the Plundering of Tangible Heritage Resources in Nigeria // Anthropology and Ethnology Open Access Journal. 2020. Vol. 3, is. 1. P. 1-4.

98. Grove L. Heritocide? Defining and exploring heritage crimes // Public archaeology. 2013. Vol. 12, № 4. P. $242-254$.

99. Layton R., Wallace G. Is culture a commodity? // The ethics of archaeology: philosophical perspectives on archaeological practice. Cambridge : Cambridge University Press, 2006. P. 46-68.

100. Gurr T.R., Harff B. Ethnic conflict in world politics. Boulder : Westview, 1994. 250 p

101. Horowitz D.L. The deadly ethnic riot. Berkeley : University of California Press, 2001. 605 p.

102. Schönle A. Ruins and History: Observations on Russian Approaches to Destruction and Decay // Slavic Review. 2006. Vol. 65, № 4. P. 649-669.

103. Handler R. Is "identity" a useful cross-cultural concept? // Commemorations. The politics of national identity. Princeton, New Jersey : Princeton University Press, 1994. P. 27-40.

104. Rowlands M. The politics of identity in archaeology // Social construction of the past: representation as power. London : Routledge, 1994. P. 129-143.

105. Hodder I. Is a Shared Past Possible? The Ethics and Practice of Archaeology in the Twenty-First Century // New Perspectives in Global Public Archaeology. New York : Springer Science + Business Media, LLC, 2011. P. 19-28.

106. Fagan G.G., Feder K.L. Crusading against straw men: an alternative view of alternative archaeologies: response to Holtorf (2005) // World Archaeology. 2006. Vol. 38, № 4. P. 718-729. 
107. Шнирельман В.А. Этничность в археологии - реальность или фантом? // Этничность в археологии или археология этничности? : материалы круглого стола. Челябинск : ЦИКР Рифей, 2013. С. 48-79.

108. Тишков В.А. От этноса к этничности // Этнографическое обозрение. 2016. № 5. С. 5-22.

109. Giblin J.D. A reconsideration of Rwandan archaeological ceramics and their political significance in a post-genocide era // African archaeological review. 2013. Vol. 30. P. 504-529.

110. Nationalism, politics and practice of archaeology / P. Kohl, C. Fawcett (eds.). Cambridge : Cambridge University Press, 1995. 344 p.

111. Shnirelman V.A. Who gets the past? Competition for ancestors among non-Russian intellectuals in Russia. Washington ; Baltimore ; London : Woodrow Wilson Center Press and Johns Hopkins University Press, 1996. 112 p.

112. Holtorf C. What's wrong with cultural diversity in world archaeology? // Claroscuro. Revista del Centro de Estudios sobre Diversidad Cultural. 2017. Vol. 16. P. 1-14

113. Шнирельман В.А. «Порог толерантности»: Идеология и практика нового расизма. М. : НЛО, 2011. Т. 1. 552 с.; Т. 2.856 с.

114. Hutchings R. "Hard Times Bring Hard Questions". Is Archaeology Pro-Development? Is it Classist? Colonialist? Imperialist? Racist? Vancouver, 2013. P. 12-14. URL: http://ubc.academia.edu/RichardHutchings/

Victor A. Shnirelman, Institute of Ethnology and Anthropology RAS (Moscow, Russian Federation). E-mail: shnirv@ mail.ru ARCHAEOLOGY, CULTURE HERITAGE, VANDALISM AND ARMED CONFLICTS

Keywords: archaeology; culture heritage; conflicts; wars; vandalism; ethics.

The article focuses on the fate of the culture heritage under modern armed conflicts and on the challenges it brings about to archaeologists. The author surveys a vast literature on the destruction of archaeological sites and looting of the museum's collections in the course of contemporary wars as well as attacks on the archaeologists and a respond from them.

A study of the modern international, inter-ethnic and religious conflicts demonstrates that an important aspect of their ideology is a reference to history, which provides a conflict with a symbolic language. In search of a legitimacy of their actions and demands the both hostile groups refer to culture heritage, which, as a result, is actively involved in the armed struggle. Thus, culture heritage is insecure and faces a mortal danger, because people believe that its destruction undermines enemy's morale and challenges the world public opinion as well as modern values.

A destruction of culture heritage pursues the following objectives: firstly, looting and trade with antiquities; secondly, an enemies' deprivation of historical resources, which could be mobilized to legitimate their demands; thirdly, a denial of the inappropriate (pagan) ancestors; fourthly, a struggle against infidels by annihilation of their important religious symbols; fifthly, a destruction of the neocolonial and despotic symbols that are sometimes associated with archaeology; and sixthly, a deprivation of the minorities' historical heritage for the sake of national unity and consolidation. Over the last twenty to twenty five years an encroachment on the other's culture heritage is often brought about by religious factors, and a religious renaissance is accompanied with a destructive activity of religious radicals and fundamentalists. They are mostly Moslems, but one can find vandals among Christians, Hindus and some others as well.

Under this environment archaeology sometimes suffers from the attacks as it is accused of a service for hated regime or imperialism and neo-colonialism. Thus, quite unexpectedly, archaeologists find themselves at the center of a political struggle, and have to make a choice between various political lines. All this requires archaeologists to have a fine understanding of how and to what extent their scholarly materials and activity serve politics, which is far from their professional field, as well as who is a subject and who is a victim of this politics, and what are its goals.

In addition, archaeologists have to overcome the former essentialism, which makes up a basis of their ethnogenetic constructions, which are extensively used and abused by the modern ethno-nationalist politics with its passion for references to historical rights. One has to consider that in the modern world archaeology plays an important social role, and the data on the deep past can be used to serve certain ethnic politics. That is why, an interpretation of this sort of materials and their offer to general public demands for a sense of delicacy and a good knowledge of the modern ethno-political environment.

\section{REFERENCES}

1. Wright, P. (1985) On Living in an Old Country. The National Past in Contemporary Britain. London: Verso.

2. Hewison, R. (1987) The Heritage Industry: Britain in a Climate of Decline. London: Methuen Publishing Ltd.

3. Fowler, P. (1992) The Past in Contemporary Society: Then, Now. London: Routledge.

4. Lowenthal, D. (1998) The Heritage Crusade and the Spoils of History. Cambridge: Cambridge University Press.

5. Brown, M.F. (2003) Who owns native culture? Cambridge: Harvard University Press.

6. Smith, L. (2006) Uses of heritage. London: Routledge.

7. Hamilakis, Y. (2003) Iraq, stewardship and 'the record': an ethical crisis for archaeology. Public Archaeology. 3(2). pp. 104-111. DOI: 10.1179/pua.2003.3.2.104

8. Hamilakis, Y. (2007) From ethics to politics. In: Hamilakis, Y. \& Duke, Ph. (eds) Archaeology and Capitalism: From Ethics to Politics. Walnut Creek, CA: Left Coast Press. pp. 15-40.

9. Green, L. (2015) Archaeologies of Intellectual Heritage? In: Gnecco, C. \& Lippert, D. (eds) Ethics and archaeological praxis. New York: Springer. pp. 229-243

10. Haber, A. (2015) Archaeology after archaeology. In: Haber, A. \& Shepherd, N. (eds) After Ethics: Ancestral Voices and Post-Disciplinary Worlds in Archaeology. New York: Springer New York. pp. 127-137.

11. Shnirelman, V.A. (2003) Voyny pamyati: mify, identichnost' i politika v Zakavkaz'e [Wars of Memory: Myths, Identity, and Politics in Transcaucasia]. Moscow: Akademkniga.

12. Shnirelman, V.A. (2006) Byt' alanami. Intellektualy i politika na Severnom Kavkaze v XX veke [To Be the Alans. Intellectuals and Politics in the North Caucasus in the 20th century]. Moscow: NLO.

13. Gamboni, D. (1997) The Destruction of Art: Iconoclasm and Vandalism since the French Revolution. London: Reaktion Books.

14. Bevan, R. (2006) The Destruction of Memory. Architecture at War. London: Reaktion Books.

15. Chapman, J. (1994) Destruction of a common heritage: the archaeology of war in Croatia, Bosnia and Hercegovina. Antiquity. 68(258). pp. 120-126. DOI: $10.1017 /$ S0003598X00046251

16. Kaiser, T. (1995) Archaeology and ideology in southeast Europe. In: Kohl, P.L. \& Fawcett, C. (eds) Nationalism, Politics and the Practice of Archaeology. Cambridge: Cambridge University Press. pp. 99-119.

17. Silberman, N.A. (1989) Between Past and Present. Archaeology, Ideology, and Nationalism in the Modern Middle East. New York: Anchor Books. 
18. Garen, M. (2004) The War within the War. Archaeology. July/August. pp. 28-31.

19. Šulc, B. (2005) The protection of Croatia's cultural heritage during war 1991-95. In: Layton, R.. Stone, P.G. \& Thomas, J. (eds) Destruction and Conservation of Cultural Property. London, New York: Routledge. pp. 157-167.

20. Defreese, M. (2009) Kosovo: Cultural Heritage in Conflict. Journal of Conflict Archaeology. 5(1). pp. 257-269. DOI: $10.1163 / 157407709 X 12634580640614$

21. Stone, P.G. \& Farchakh Bajjaly, J. (eds) (2008) The Destruction of Cultural Heritage in Iraq. Woodbridge: The Boydell Press. pp. 1-17.

22. Rothfield, L. (ed.) 2008) Antiquities under Siege. Cultural Heritage Protection after the War in Iraq. Lanham, MD : Altamira Press.

23. Cobb, E. (2010) Cultural Heritage in Conflict: World Heritage Cities of the Middle East. (Masters Thesis). Philadelphia: University of Pennsylvania.

24. Auwera, S. van der (2012) Contemporary Conflict, Nationalism, and the Destruction of Cultural Property during Armed Conflict: A Theoretical Framework. Journal of Conflict Archaeology. 7(1). pp. 49-65. DOI: 10.1179/157407812X13245464933821

25. Faustova, M. (2012) Rossiya pomozhet vosstanovit' utrachennye svyatyni Kosovo [Russia will help restore the lost shrines of Kosovo]. Golos Rossii. 16th March. [Online] Available from: http://rus.ruvr.ru/2012 03 16/68672459

26. Emberling, G. \& Hanson, K. (eds) (2008) Catastrophe! The Looting and Destruction of Iraq's Past. Chicago: The Oriental Institute Museum of the University of Chicago.

27. Zhurenkov, K. \& Epifanova, M. (2011) Pokhishchenie vekov [The abduction of centuries]. Ogonek. 21st February. [Online] Available from: http://www.kommersant.ru/doc/1580743

28. Regnum. (2011a) Egipet: maroderstvo prodolzhaetsya [Egypt: looting continues] 2nd March. [Online] Available from: http://www.regnum.ru/news/1379839.html

29. Regnum. (2011b) Opublikovan itogovyy spisok poter' v Kairskom muzee [The final list of losses in the Cairo Museum has been published]. 16th March. [Online] Available from: http://www.regnum.ru/news/1384090.html

30. Layton, R. \& Wallace, G. (2006) Is culture a commodity? In: Scarre, Ch. \& Scarre, G. (eds) The Ethics of Archaeology: Philosophical Perspectives on Archaeological Practice. Cambridge : Cambridge University Press. pp. 46-68.

31. Hollowell, J. (2006) Moral arguments on subsistence digging. In: Scarre, Ch. \& Scarre, G. (eds) The Ethics of Archaeology: Philosophical Perspectives on Archaeological Practice. Cambridge : Cambridge University Press. pp. 69-93.

32. Rush, L.W. (2015) Partnership versus Guns: Military Advocacy of Peaceful Approaches for Cultural Property Protection. In: González-Ruibal, A. \& Moshenska, G. (eds) Ethics and the Archaeology of Violence. New York: Springer. pp. 181-198.

33. Hardy, S. (2015) Virtues Impracticable and Extremely Difficult: The Human Rights of Subsistence Diggers. In: González-Ruibal, A. \& Moshenska, G. (eds) Ethics and the Archaeology of Violence. New York: Springer. pp. 229-239.

34. Bendremer, J.C. \& Richman, K.A. (2006) Human subjects review and archaeology: a view from Indian country. In: Scarre, Ch. \& Scarre, G. (eds) The Ethics of Archaeology: Philosophical Perspectives on Archaeological Practice. Cambridge : Cambridge University Press. pp. 97-114.

35. Hassan, F. (1998) Memorabilia: archaeological materiality and national identity in Egypt. In: Meskell, L. (ed.) Archaeology under fire: nationalism, politics and heritage in the Eastern Mediterranean and Middle East. London: Routledge. pp. 200-216.

36. Badran, A. (2011) The Excluded Past in Jordanian Formal Primary Education: The Introduction of Archaeology. In: Okamura, K. \& Matsuda, A. (eds) New Perspectives in Global Public Archaeology. New York: Springer Science+Business Media, LLC. pp. 197-215.

37. Abdi, K. (2001) Nationalism, politics, and development of archaeology in Iran. American Journal of Archaeology. 105(1). pp. 51-76. DOI: 10.4000/abstractairanica.4044

38. Dezhamkhooy, M., Yazdi, L.P. \& Garazhian, O. (2015) All Our Findings Are Under Their Boots! The Monologue of Violence in Iranian Archaeology. In: González-Ruibal, A. \& Moshenska, G. (eds) Ethics and the Archaeology of Violence. New York: Springer. pp. 51-70.

39. Flood, F.B. (2002) Between cult and culture: Bamiyan, Islamic iconoclasm, and the museum. The Art Bulletin. 84(4). pp. 641-659. DOI: $10.2307 / 3177288$

40. Colwell-Chanthaphonh, C. (2003) Dismembering/disremembering the Buddhas? Renderings on the Internet during the Afghan purge of the past. Journal of Social Archaeology. 3(1). pp. 75-98. DOI: 10.1177/1469605303003001100

41. Huyssen, A. (2003) Present pasts: urban palimpsests and the politics of memory. Stanford: Stanford University Press. pp. 161-162.

42. Silberman, N.A. (2001) If I forget thee, O Jerusalem: archaeology, religious commemoration and nationalism in a disputed city, 1801-2001. Nations and Nationalism. 7(4). pp. 487-504. DOI: 10.1111/1469-8219.00029

43. Newsru. (2012) Islamisty na Mal'divakh unichtozhili v mestnom muzee kollektsiyu iz 30 statuy Buddy [Islamists in the Maldives destroyed a collection of 30 Buddha statues in a local Museum]. 17th February. [Online] Available from: http://www.newsru.com/religy/17feb2012/maldives.html

44. RBK. (2012) Islamisty razrushili do osnovaniya pamyatnik YuNESKO [Islamists destroyed the UNESCO monument to the ground]. 30th July. [Online] Available from: http://top.rbc.ru/society/30/06/2012/657690.shtml

45. Solovieva, N.V. (2012) V Mali islamisty razrushili neskol'ko svyatyn' - zakhoroneniy [In Mali, Islamists have destroyed a number of shrines graves]. [Online] Available from: http://www.internovosti.ru/text/?id=65502

46. Colwell, Ch. \& Joy, Ch. (2015) Communities and Ethics in the Heritage Debates. Global Heritage: A Reader. 1. pp. 112-130.

47. Faustova, M. \& Petrova, A. (2012) Araviyskaya tolerantnost' [Arabian tolerance]. Golos Rossii. 20th March. [Online] Available from: http://rus.ruvr.ru/2012_03_20/68985207/

48. Miklashevskaya, A. (2015) IGIL srovnyal s zemley istoriyu Assirii [ISIS has leveled the history of Assyria]. Kommersant-Online. 6th March. [Online] Available from: https://news.mail.ru/incident/21296437/?frommail=1

49. Novaya gazeta. (2015) "Islamskoe gosudarstvo" opublikovalo video unichtozheniya drevnego goroda Hatra [ISIS published a video of ancient Hatra destruction]. 4th April.

50. Zabrodina, E. (2015) Kto spaset Pal'miru? [Who will save Palmyra?]. Rossiyskaya gazeta. 21st May.

51. Rozhdestvenskaya, Ya. (2015) Boeviki "Islamskogo gosudarstva" nachali razrushat' Pal'miru [The militants of the "Islamic state" began to destroy Palmyra]. Kommersant. 25th June.

52. Lenta.ru. (2015) Boeviki IG razbili kuvaldami shest' statuy v Pal'mire [ISIS militants smashed six statues with sledgehammers in Palmyra]. 3rd July. [Online] Available from: https://news.mail.ru/incident/22547069

53. Filipenok, A. (2017) Boeviki IG razrushili chast' rimskogo amfiteatra v Pal'mire [ISIS militants destroyed part of the Roman amphitheater in Palmyra]. $R B K$. 20th January. [Online] Available from: http://www.rbc.ru/society/20/01/2017/5881ca5e9a79472a1664c588?from=newsfeed

54. Luke, Ch. \& Meskell, L. (2019) Archaeology, assistance, and aggression along the Euphrates: reflections from Raqqa. International Journal of Cultural Policy. 2nd April. [Online] Available from: https://doi.org/10.1080/10286632.2019.1598398

55. Dopelhofer, Ch. (2016) Will Palmyra rise again? - War Crimes against Cultural Heritage and Post-war reconstruction. [Online] Available from: http://www.ohchr.org/EN/Issues/CulturalRights/ Pages/IntentionalDestruction.aspx

56. Holtorf, C. (2006) Can less be more? Heritage in the age of terrorism. Public Archaeology. 5. pp. 101-109. DOI: 10.1179/pua.2006.5.2.101

57. Harmansah, Ö. (2015) ISIS, heritage, and the spectacles of destruction in the global media. Near Eastern Archaeology. 78(3). pp. 170-177. DOI: 10.5615/neareastarch.78.3.0170

58. Smith, C., Burke, H., de Leiuen, C. \& Jackson, G. (2015) The Islamic State's symbolic war: Da'esh's socially mediated terrorism as a threat to cultural heritage. Journal of Social Archaeology. 16(2). pp. 164-188. DOI: 10.1177/1469605315617048

59. Pollock, S. (2016) Archaeology and contemporary warfare. Annual Review of Anthropology. 45. pp. 215-231. DOI: 10.1146/annurev-anthro-102215095913 
60. Shahab, S. \& Isakhan, B. (2018) The ritualization of heritage destruction under the Islamic State. Journal of Social Archaeology. 2. pp. $212-233$. DOI: $10.1080 / 09546553.2017 .1398741$

61. De Cesari, C. (2015) Post-colonial ruins: Archaeologies of political violence and IS. Anthropology Today. 31(6). pp. 22-26. DOI: 10.1111/14678322.12214

62. Smith, L. (2004) Archaeological Theory and the Politics of Culture Heritage. New York: Routledge.

63. Nicholas, G. \& Hollowel, J. (2007) Ethical Challenges to a Postcolonial Archaeology: the Legacy of Scientific Colonialism. In: Hamilakis, Y. \& Duke, P. (eds) Archaeology and Capitalism: From Ethics to Politics. Walnut Creek: Left Coast Press. pp. 59-82.

64. Yahya, A. (1998) The Archaeological Sites of the West Bank and Gaza. Al Bireh: Abu Ghosh Press.

65. Kersel, M.M. (2007) Transcending borders: objects on the move. Archaeologies: Journal of the World Archaeological Congress. 3(2). pp. 91-94. DOI: $10.1007 / \mathrm{s} 11759-007-9013-0$

66. Al-Hamdani, A.M. (2008) Protecting and recording our archaeological heritage in southern Iraq. Near Eastern Archaeology. 71(4). pp. 223-224. DOI: $10.1086 /$ NEA20697192

67. Lababidi, R. \& Qassar, H. (2016) Did They Really Forget How to Do It? Iraq, Syria, and the International Response to Protect a Shared Heritage. Journal of Eastern Mediterranean Archaeology \& Heritage Studies. 4(4). pp. 341-362. DOI: 10.5325/jeasmedarcherstu.4.4.0341

68. Leckie, L., Cunliffe, E. \& Varoutsikos, B. (2017) Towards a protection of the Syrian cultural heritage: a summary of the national and international responses. Vol. IV. Girona: Heritage for Peace.

69. Albarella, U. (2009) Archaeologists in Conflict: Empathizing with Which Victims? Heritage Management. 2(1). pp. 105-114. DOI: 10.1179/hso.2009.2.1.105

70. Schoenbaum, D. (2016) The violins of Palmyra: Soft power projection, then and now. Foreign Affairs. 26th May.

71. Plets, G. (2017) Violins and trowels for Palmyra: Post-conflict heritage politics. Anthropology Today. 33(4). pp. 18-22. DOI: 10.1111/14678322.12362

72. Knap, A.B. \& Antoniadou, S. (1998) Archaeology, politics and the cultural heritage of Cyprus. In: Meskell. L. (ed.) Archaeology Under Fire: Nationalism, Politics and Heritage in the Eastern Mediterranean and Middle East. London: Routledge. pp. 13-43.

73. Shnirelman, V.A. (2012) Religiya, natsionalizm i mezhkonfessional'nyy konflikt $v$ Indii [Religion, Nationalism and Interfaith Conflict in India]. In: Tishkov, V.A. \& Shnirelman, V.A. (eds) Etnichnost' i religiya v sovremennykh konfliktakh [Ethnicity and Religion in Contemporary Conflicts]. Moscow: Nauka. pp. 57-109.

74. Tanner, M. (1997) Croatia: A Nation Forged in War. New Haven: Yale University Press. pp. 285-294.

75. Barakat, S., Wilson, C., Simcic, V. S. \& Kojakovic, M. (2001) Challenges and Dilemmas Facing the Reconstruction of War-Damaged Cultural Heritage: The Case Study of Pocitelj, Bosnia-Herzegovina. In: Layton, R., Stone, P. \& Thomas, J. (eds) The Destruction and Conservation of Cultural Property. London: Routledge. pp. 168-181.

76. Riedlmayer, A.J. (2002) Destruction of Cultural Heritage in Bosnia-Herzegovina, 1992-1996: A Post-War Survey of Selected Municipalities. Cambridge, Massachusetts. [Online] Available from: http://hague.bard.edu/reports/BosHeritageReport-AR.pdf

77. Hamilakis, Y. (2009) The 'war on terror' and the military-archaeology complex: Iraq, ethics, and neocolonialism. Archaeology: Journal of the World Archaeological Congress. 5(1). pp. 39-65. DOI: 10.1007/s11759-008-9076-6

78. Perring, D. \& van der Linde, S. (2009) The Politics and Practice of Archaeology in Conflict. Conservation and Management of Archaeological Sites. 11(3-4). pp. 197-213. DOI: 10.1179/175355210X12747818485321

79. Stone, P. (2009) Archaeology and Conflict: An Impossible Relationship? Conservation and Management of Archaeological Sites. 11(3-4). pp. 315332. DOI: $10.1179 / 175355210 X 12747818485565$

80. Rush, L.W. (2015) Partnership Versus Guns: Military Advocacy of Peaceful Approaches for Cultural Property Protection. In: González-Ruibal, A. \& Moshenska, G. (eds) Ethics and the Archaeology of Violence. New York: Springer. pp. 181-197.

81. Congram, D. (2015) Cognitive Dissonance and the Military-Archaeology Complex. In: González-Ruibal, A. \& Moshenska, G. (eds) Ethics and the Archaeology of Violence. New York: Springer. pp. 198-213.

82. Shnirelman, V. (2005) Politics of ethnogenesis in the USSR and after. Bulletin of the National Museum of Ethnology. 30(1). pp. 93-119. DOI: $10.15021 / 00003990$

83. Shnirelman, V.A. (2009) Prezidenty i arkheologiya, ili chto ishchut politiki v drevnosti [Presidents and archeology, or what politicians are looking for in antiquity]. Ab Imperio. 1. pp. 279-323.

84. Shanks, M. \& Tilley, C. (1987) Re-constructing archaeology. Cambridge: Cambridge University Press.

85. Hamilakis, Y. \& Duke, P. (eds) Archaeology and Capitalism: From Ethics to Politics. Walnut Creek, CA: Left Coast Press.

86. Makarov, N.A. (2004) Grabitel'skie raskopki kak faktor unichtozheniya arkheologicheskogo naslediya Rossii [Predatory excavations as a factor in the destruction of Russia's archaeological heritage]. Moscow: RAS

87. Kuban.aif.ru. (2012) V Anape vandaly razrushili altar' drevneyshego khrama [In Anapa, vandals destroyed the altar of the oldest temple]. 9th April. [Online] Available from: http://www.kuban.aif.ru/culture/news/52064

88. Soloviev, S. (2006) Okhotniki za cherepkami. Rossiya ostaetsya Mekkoy dlya "chernykh arkheologov" [Shards hunters. Russia remains a Mecca for "black archaeologists"]. Novye Izvestiya. 4th August.

89. Kersel, M.M. \& Luke, Ch. (2010) Editorial Introduction. Journal of Field Archaeology. 35(1). pp. 99-100.

90. Jacobson, D. (2014) Vandalism and worse at Herodian sites. Palestine Exploration Quarterly. 146(3). pp. 173-176. DOI: 10.1179/0031032814Z.000000000103

91. Schmidt, P.R. \& McIntosh, R.J. (eds) Plundering Africa's Past. Bloomington: Indiana University Press.

92. Renfrew, C. (2000) Loot, Legitimacy and Ownership: The Ethical Crisis in Archaeology. London: Duckworth.

93. Brodie, N., Jennifer, D. \& Renfrew, C. (eds) Trade in Illicit Antiquities: The Destruction of the World's Archaeological Heritag. Cambridge: McDonald Institute for Archaeological Research.

94. Atwood, R. (2004) Stealing History: Tomb Raiders, Smugglers, and the Looting of the Ancient World. New York: St. Martin's Press.

95. Brodie, N., Kersel, M.M., Luke, Ch. \& Walkter Tubb, K. (eds) Archaeology, Cultural Heritage, and the Antiquities Trade. Gainesville: University Press of Florida.

96. Lazrus, P. \& Barker, A. (eds) All the King's horses. Essays on the impact of looting and the illicit antiquities trade on our knowledge of the past. Washington: SAA.

97. Folorunso, C.A. (2020) Research Notes on the Plundering of Tangible Heritage Resources in Nigeria. Anthropology and Ethnology Open Access Journal. 3(1). pp. 1-4. DOI: 10.23880/aeoaj-16000131

98. Grove, L. (2013) Heritocide? Defining and exploring heritage crimes. Public Archaeology. 12(4). pp. 242-254. DOI: $10.1179 / 1465518714 Z .00000000046$

99. Layton, R. \& Wallace, G. (2006) Is culture a commodity? In: Scarre, Ch. \& Scarre, G. (eds) The ethics of archaeology: philosophical perspectives on archaeological practice. Cambridge: Cambridge University Press. pp. 46-68.

100. Gurr, T.R. \& Harff, B. (1994) Ethnic Conflict in World Politics. Boulder: Westview.

101. Horowitz, D.L. (2001) The Deadly Ethnic Riot. Berkeley: University of California Press.

102. Schönle, A. (2006) Ruins and History: Observations on Russian Approaches to Destruction and Decay. Slavic Review. 65(4). pp. 649-669. DOI: $10.2307 / 4148448$ 
103. Handler, R. (1994) Is "identity” a useful cross-cultural concept? In: Gillis, J.R. (ed.) Commemorations. The politics of national identity. Princeton, New Jersey: Princeton University Press. pp. 27-40.

104. Rowlands, M. (1994) The politics of identity in archaeology. In: Bond, G.C. \& Gilliam, A. (eds) Social construction of the past: representation as power. London: Routledge. pp. 129-143.

105. Hodder, I. (2011) Is a Shared Past Possible? The Ethics and Practice of Archaeology in the Twenty-First Century. In: Okamura, K. \& Matsuda, A. (eds) New Perspectives in Global Public Archaeology. New York: Springer Science + Business Media, LLC. pp. 19-28.

106. Fagan, G.G. \& Feder, K.L. (2006) Crusading against straw men: an alternative view of alternative archaeologies: response to Holtorf (2005). World Archaeology. 3(4). pp. 718-729.

107. Shnirelman, V.A. (2013) Etnichnost' v arkheologii - real'nost' ili fantom? [Ethnicity in archeology - reality or phantom?]. In: Mosin, V.S. \& Yablonsky, L.T. (eds) Etnichnost'v arkheologii ili arkheologiya etnichnosti? [Ethnicity in archeology or archeology of ethnicity?]. Round table materials Chelyabinsk: TsIKR Rifey. pp. 48-79.

108. Tishkov, V.A. (2016) From ethnos to ethnicity. Etnograficheskoe obozrenie - Ethnographic Review. 5. pp. 5-22. (In Russian).

109. Giblin, J.D. (2013) A reconsideration of Rwandan archaeological ceramics and their political significance in a post-genocide era. African Archaeological Review. 30. pp. 504-529. DOI: 10.1007/s10437-013-9144-1

110. Kohl, P. \& Fawcett, C. (eds) Nationalism, politics and practice of archaeology. Cambridge: Cambridge University Press.

111. Shnirelman, V.A. (1996) Who gets the past? Competition for ancestors among non-Russian intellectuals in Russia. Washington; Baltimore; London: Woodrow Wilson Center Press and Johns Hopkins University Press.

112. Holtorf, C. (2017) What's wrong with cultural diversity in world archaeology? Claroscuro. Revista del Centro de Estudios sobre Diversidad Cultural. 16. pp. 1-14. DOI: $10.1080 / 13527258.2017 .1347890$

113. Shnirelman, V.A. (2011) "Porog tolerantnosti": Ideologiya i praktika novogo rasizma ["Threshold of Tolerance": Ideology and Practice of New Racism]. Moscow: NLO.

114. Hutchings, R. (2013) "Hard Times Bring Hard Questions". Is Archaeology Pro-Development? Is it Classist? Colonialist? Imperialist? Racist? [Online] Available from: http://ubc.academia.edu/RichardHutchings 